\title{
Nigerian Transnational Companies and Economic Development across Sub-Saharan Africa
}

\author{
Obinna U. Muoh, Hero U. Obasuyi and Oge Ikem \\ University of Nigeria
}

\begin{abstract}
In examining how the private sector could be gainfully engaged in economic development of African countries, issues such as corporate social responsibility (CSR) framework, multinational enterprise and livelihood option suffice. These are some key elements of a credible policy package that will promote private sector development and boost intra-African trade. Another vital area that needs to be creatively addressed in the capacitation of African enterprises is access to financial resources, which studies suggest is one of the major constraints to private sector development in Africa. As one of the largest economies in Africa, Nigeria has played a leading role in private sector engagement in economic development. A number of Nigerian transnational companies have extended their operations and maintained active presence in some other Africa countries, particularly Sub-Saharan African countries. In addition to their primary business, they have invested heavily in some human development sectors such as health, workforce development and infrastructure - initiatives which not only benefitted them, but create richer economies and enhance human capital development of the host countries. The study is mainly focused on the capital investments of two Nigerian Transnational Companies - Globalcom, a Telecommunication company and the Dangote Group - a manufacturing and trading firm. The study uses their operations and investments across Sub-Saharan Africa as case studies of Nigeria's private firms' contribution to economic development in Africa. The study will look into published statistical records and other materials to generate information on trade and foreign investment within the study area.
\end{abstract}

Keywords: Transnational Companies, Economic Development, Africa

DOI: $10.7176 / \mathrm{IAGS} / 83-05$

Publication date:June $30^{\text {th }} 2020$

\section{Introduction}

As one of the largest economies in Africa, Nigeria has played a leading role in private sector engagement in economic development. A number of Nigerian transnational companies have extended their operations and maintained active presence in some other Africa countries, particularly Sub-Saharan African countries. In addition to their primary business, they have invested heavily in some human development sectors such as health, workforce development and infrastructure - initiatives which not only benefitted them, but create richer economies and enhance human capital development of the host countries.

Imperatively, the Nigerian government has through the Ministry of Trade, Investment and Industry created linkages with other Sub-Saharan African trading partners to facilitate investments by these Nigerian transnational companies so as to increase the levels of intra-African trade. As a result, Nigeria has been at the forefront of developing an intra-African foreign direct investment (FDI), an approach advanced by has taken the Economic Commission for Africa since the 1980s. This indigenous FDI has taken the form of business interactions and capital investments in manufacturing industries, financial services and communication. Brazing the trail in this regard are Nigerian transnational companies--Dangote Group, which established cement manufacturing plants and import terminals for its food trade in Cameroun, Congo, Ethiopia, Senegal, South Africa and Zambia, among others. In addition, Globacom, a privately-owned Nigerian telecommunication company is currently operating in Republic of Benin, Ghana and Cote d'Ivoire. These expansions have provided opportunities for focused and effective trade engagements, stronger economic relations, and most importantly infrastructural and industrial development with the host countries. These endeavours appear to have demonstrated proponents of intra-African trade and the role of the private sector in boosting Africa's economies through long-term investments, internal efficiencies, and overall value creation.

While some writers have tried to close the gap in the dearth of literature on African economic integration scholarship by comparing its regional integration to other world regions, such efforts either still remain statecentric or simply continue to singularize and simplify neoliberalism as the reason for the resurgence of African integration. The paucity of scholarship on the integration effects of business in Africa suggests more about the 
theoretical blinders we have been collectively wearing than anything about the real world of regional interactions in Africa over the past two decades.

In addition to its documented contribution to growth, private investment in the case of Africa deserves serious attention for three additional reasons. First, sustained increase in private investment serves as a visible proof of the private sector's confidence in public policy both in the sense that policy is heading in the right direction and that policy reforms are deemed sustainable in the long run (Ndikumana, 2005) Achieving the growth rates needed to alleviate poverty and raise employment will require active participation of private investors. Second, sustained increase in private investment is a sign of efficiency of public investment especially in reducing the costs of private investment, thus raising profitability. Third, sustained improvement in private investment serves as a medium for attracting foreign direct investment as it is an indicator of high returns to investment and declining risk of investment in the country

However, attention given to promote domestic investment in Africa is rather below par relative to other regions of the world (United Nations Economic Commission for Africa 1995; IMF, 2009). The rate of return on both capital and labour and the overall productivity of the Sub- Saharan African economies remain low because of a variety of distortions and institutional deficiencies (Sima, 2007). The problems according to Jecheche (2011) include obstacles to international trade, overvalued exchange rate, poor infrastructure, bad governance \&corruption, insufficient competition \& monopolistic structures in many of the sectors. It has always been argued, in one way or another, that all of these problems are related to the policies formulated in these countries.

Sub-Saharan transnational corporations have received relatively little attention in the global business media despite dramatic growth in the past several years both in revenue and in the scale of expansion across borders. They are expanding across the region, even into markets that global multinationals may have considered unprofitable, too complex or even dangerous. The biggest transnationals have turnover of more than $\$ 1$ billion a year and many have opened operations not just in other African countries but on other continents as well. Their business lines cover a range of goods, such as petroleum and electronics, and services, such as insurance and tourism. It is dismal that the contributions of some key African transnational companies in trade and capital investments across Africa have not gained concerted attention in economic development scholarship.

The broad objective of this work is to examine the contributions of private foreign investment in intra-regional trade within Sub- Saharan African countries. In doing so, it aspires to contribute to empirical literature on the effect of investments and trade on the performance of economic integration in the region.

This study will adopt the qualitative research method. The main source of data collection for this study is secondary data. The study will look into published statistical records and other materials to generate information on trade and foreign investment within the study area. For the purpose of this study, investment will include all inflow of Nigeria foreign capital into other African countries which are in the forms of foreign portfolio investment, inflow of foreign loan to private business and other types of inflow The data for this study was collected from statistical databases on imports and exports fromCentral Bank of Nigeria, National Burean of Statistics, official publications of banks and companies studies, and data from National Burean of StatisticsTrade and investment data were collected from the databases of some international economic organizations such asInternational Monetary Fund (IMF), United Nations Conference on Trade and Development (UNCTAD), World Trade Organization (WTO), Organization for Economic Cooperation and Development (OECD), and other trade indexing agencies' database on Africa. Other secondary source includes Internets materials, Published books, journal articles and reports. The statistical method of analysis will be quantitative descriptive method. Quantitative descriptive will help summarize our data while sampling statistics will be applied to evaluate the data. As a result, measure of central tendency like the percentage will be used. Also tables and graphs will be applied to see trends. This will enable us to know the characteristics, variation, distribution and relationship in Nigerians trade and foreign investment across Sub-Saharan Africa.

\section{Definition of Terms}

\section{Transnational Companies (TNCs)}

The term "transnational corporation" as used in this study means an enterprise, comprising entities in two or more countries, regardless of the legal form and fields of activity of these entities, which operates under a system of decision-making, permitting coherent policies and a common strategy through one or more decision-making centres, in which the entitles are so linked, by ownership or otherwise, that one or more of them may be able to exercise a significant influence over the activities of others, and, in particular, to share knowledge, resources and responsibilities with the others. (Claessens and Lee (2002) 


\section{Economic Development}

Economic development from a policy perspective can be defined as efforts that seek to improve the economic well-being and quality of life for a community by creating and/or retaining jobs and supporting growing incomes and the tax base. Thu, the term 'economic development' refers to improvements in a variety of indicators, such as literacy rate, life expectancy, and poverty rates. (Todaro,1994)

It is a process whereby simple, low-income national economies are transformed into modern industrial economies.

In a broadest sense, economic development encompasses three major areas;

1. Policies that government undertakes to meet broad economic objectives such as price stability, high employment, expanded tax base, and sustainable growth. Such efforts include monetary and fiscal policies, regulation of financial institutions, trade, and tax policies.

2. Policies and programmes to provide infrastructure and services such as highways, affordable housings and educational programmes.

3. Policies and programmes directed at job creation (Todaro,1994).

\section{Literature Review}

Previous studies on the Foreign Direct Investment (FDI) and economic growth in Nigeria and other countries provided inconclusive evidence. Lall (2002) opined that FDI inflow affects many factors in the economy and these factors in turn affect economic growth. This review shows that the debate on the impact of FDI on economic growth is far from being conclusive. The role of FDI seems to be country specific and can be positive, negative or insignificant, depending on the economic, institutional and technological conditions in the recipient countries. For instance, Solomon and Eka (2013) investigated the empirical relationship between Foreign Direct Investment and economic growth in Nigeria. The work covered a period of 1981-2009 using an annual data from Central Bank of Nigeria statistical bulletin. A growth model via the Ordinary Least Square method was used to ascertain the relationship between FDI and economic growth in Nigeria. The result of the OLS techniques indicated that FDI has a positive but has insignificant impact on Nigerian economic growth for the period under study. Alejandro (2010) explained that FDI plays an extra ordinary and growing role in global business and economics. It can provide a firm with new markets and marketing channels, cheaper production facilities access to new technology products, skills and financing for a host country or the foreign firms which investment, it can provide a source of new technologies, capital processes products, organization technologies and management skills and other positive externalities and spillover that can provide a strong impetus to regional economic growth. Obwona (2001) noted in his study of the determinants of FDI and their impact on growth in Uganda that macroeconomic and political stability and policy consistency are important parameters determining the inflow of Foreign Direct Investment (FDI) into Uganda and that Foreign Direct Investment (FDI) affects growth positively but insignificant. Foreign Direct Investment (FDI) also contributes to economic growth via technology transfer. Zhang (2001) argued that Foreign Direct Investment has positive growth impact that is similar todomestic investment along with partly alleviating balance of payment deficit in the currentaccount. He opined that via technology transfer and spillover efficiency, the inflow of directforeign investment might be able to stimulate a country economic performance. Ewe-Ghee Lim (2001) summarized recent arguments and findings on FDI and its correlation with economic growth focusing on literature regarding spillovers from FDI and found that while substantial support exists for positive spillovers from FDI, there is no consensus on casualty. Otepola (2002) also examined the importance of direct foreign investment in Nigeria. The study empirically examined the impact of FDI on growth. He concluded that FDI contributes significantly to growth especially through exports. Ricardo, Hwang and Rodrick (2005) argued that Foreign Direct Investment (FDI) provide a path for emerging nations to export the products developed economies usually sell, in effect increasing their export sophistication. Many developing countries pursue FDI as a tool for export promotion, rather than production for the domestic economy. Typically foreign investors build plants in nations where they can produce goods for export at lower costs. Bende-Nabende (2002) also found that direct long term impact of Foreign Direct Investment (FDI) on output is significant and positive for comparatively economically less-advanced Philippines and Thailand, but negative in the more economically advanced Japan and Taiwan. In the same line, Ariyo (1998) studied the investment trend and its impact on Nigeria's economic growth over the years. He found that only private domestic investment consistently contributed to raising GDP growth rates during the period considered (1970-1995). However, Alfaro et al, (2003) affirmed that the contribution of FDI to growth depends on the sector of the economy where the FDI operates. He claimed that FDI inflow to the primary sectors, tends to have a negative effect on growth, however, as for the service sector, the effect of DFI inflow is not so clear. Durharm (2004) for example, failed to establish a positive relationship between Foreign 
Direct Investment (FDI) and growth but instead suggests that the effects of Foreign Direct Investment (FDI) are contingents on the absorptive capability of host countries. Nwankwo et al, (2013) investigated the impact of globalization on foreign direct investment in Nigeria-since the world has become a global village. The methodology used is purely descriptive and narrative and the data used is secondary. It was found out that foreign direct investment (FDI) has been of increased benefit to Nigeria in the area of employment, transfer of technology, encouragement of local enterprises etc. But there are certain impediments to the full realization of the benefits of foreign direct investment. Adelegan (2000) also explored the seemingly unrelated regression model to examine the impact of FDI on economic growth in Nigeria and found out that FDI is pro-consumption and pro-import and negatively related to gross domestic investment. In the same line, Ogiogio (1995) reported negative contributions of public investment to GDP growth in Nigeria for reasons of distortions. Oyinlola (1995) also conceptualized foreign capital to include foreign loans, direct foreign investments and export earnings. Using Chenery and Stout's two-gap model (Chenery and Stout, 1966), he concluded that FDI has a negative effect on economic development in Nigeria.

Earlier studies of private investment in developing countries thus opted to move away from the traditional theories and placed emphasis on the role of financial sector development. They highlighted the fact that financial markets in developing countries are typically repressed and firms are credit rationed constraining their ability to adjust capital to a desired level. More specifically limited access to credit forces firms in developing countries to accumulate enough real balances before initiating investment projects. Mckinnon (1973) and Shaw(1973) provided the theoretical and empirical framework for such analyses and they argued that the level and quality of private investment in developing countries is positively associated with the real interest rate on deposits. This proposition was in contradiction with the neoclassical model where interest rate is treated as the user cost of capital. Evidence in support of the Mckinnon-Shaw thesis was however generally missing and mixed at best. Nonetheless studies along this line alerted subsequent researchers to incorporate availability of credit as a determinant of private investment in developing countries instead of relying only on interest rates which are administratively controlled

Obviously, empirically studies on Trade-private investment nexus devoted to Sub-Saharan Africa are still scanty, others conducted inter-regional studies of developing countries collectively. The methodologies adopted in the aforementioned works are either cross- section or time-series in nature,Apart from this, several studies discussed were concerned with either investigating the relationship between public expenditure and growth with investment playing a secondary role.

Asante (2000) study sought to examine the determinants of private investment in Ghana over the period 19701992. The results showed that the variables that had a significant positive relationship with investment are: lagged investment, public investment, private sector credit, real interest rate, and real exchange rate. Trade, political instability, macroeconomic instability, and the growth rate of real GDP have had a negative relationship with private investment.

Ndikumana (2000) examined the financial determinants of domestic investment in Sub-Saharan Africa. The study employs panel data for thirty countries over the period 1970-1995. The results indicate a positive relationship between both total and private investment and 3 indicators of financial development, while credit to the public sector is negative and significantly related to investment. When control variables are included in the regressions, the results show that investment is negatively related to the debt service, debt stock, the black market premium, and inflation. Investment is positively related to per capita GDP growth and international trade flows. The author concludes that financial factors are important in determining domestic investment in Sub-Saharan Africa, and that strong financial development leads to high future investment levels, with private investment reacting more strongly than total investment.

Moshi and Kilindo (1999) conducted an empirical study on the role of government policy on private investment in Tanzania using data over the period 1970-1992. The results of regression estimates showed a positive and significant relationship betweenprivate investment and GDP growth, private sector credit, and public investment. The authors used another specification where public investment was split into central government investment and parastatal sector investment. The estimated results showed that all the variables were positive and statistically significant with the exception of central government investment which was significantly negative, thus providing evidence of crowding-out.

Ndikumana (2000) examined the financial determinants of domestic investment in Sub-Saharan Africa. The study employs panel data for thirty countries over the period 1970-1995. The results indicate a positive relationship 
between both total and private investment and 3 indicators of financial development, while credit to the public sector is negative and significantly related to investment. When control variables are included in the regressions, the results show that investment is negatively related to the debt service, debt stock, the black market premium, and inflation. Investment is positively related to per capita GDP growth and international trade flows. The author concludes that financial factors are important in determining domestic investment in Sub-Saharan Africa, and that strong financial development leads to high future investment levels, with private investment reacting more strongly than total investment.

Akpokodje's (2000) sought to explore the association between export earnings fluctuations and capital formation in Nigeria over the period 1960-1995. The explanatory variables were savings, output, and the rate of interest. The authors found a significant positive relationship between capital stock and savings and output. The interest rate was negative and statistically insignificant.

Oshikoya (1994) examined the determinants of private investment in eight African countries for the period 19701988. The results show that the growth rate of real GDP, the public investment ratio, and the availability of credit all have a positive impact on private investment. The debt service ratio has a negative effect on private investment.

\section{The Rise of African Trannational Corporations}

In the last few years, , some major African companies began diversifying their business operations across African and outside Africa. These expansions were characterized by their diversity in terms of industries and geography. Some of these notable companies include; SABMiller, MTN, Naspers, BHP Billiton, Richemont, Sasol, Shoprite, Airtel Africa, Dangote Group, Oando and Capitec among others.(The Africa Report, 2017)

South Africa is the leading country in the efforts at entrenching African transnational companies across Africa. The MTN Group is a South African-based multinational mobile telecommunication company operating in 21 countries across the region+. Its head office is in Johannesburg. Shoprite is another South African-based retail and fast food company. It operates over 1200 corporate and 270 franchise outlets in 16 countries across Africa. Sasol is an integrated energy and chemical company that is owned by South Africans. It has explorations and sales operations in southern African countries, Naspers is a South African-based multinational mass media company with principal operation in electronic media - including pay-television operating across African countries.(The Africa Report, 2017)

West Africa also boasts other indigenous large region-centric companies, such as Nigerian Breweries Pic (a food and beverages company with $\$ 3$ billion market value); the $\$ 15$ billion worth Nigeria-based Dangote Group of Companies (whose founder, Aliko Dangote, is the richest African according to Forbes magazine); Cote d'lvoire's Sonatel (a telecommunications company; \$1.76 billion); Sonatel of Senegal (\$2.7 billion); Nigeria-based Oando Petroleum Company (\$300 million) and Globacom cell phone company (African Business, April 2007). The financial weight of the region's cross-border MNBEs dwarfs the $\$ 1.1$ billion and $\$ 1.3$ billion in official exports and imports trade, respectively, among Ghana,

At the height of the recent global economic downturn, Changes in Sub-Saharan Africa's political and economic environment have set the stage for MNCs' growth, with democratization and economic integration making the biggest impact. The spread of democracy is gradually making economic systems more meritocratic, opening up entrepreneurial opportunities and fostering a new middle class. Meanwhile, economic integration - though slow in some areas - is eliminating barriers to cross-border commerce. These companies are quickly becoming a force to be reckoned with in one of the world's most dynamic markets. They are the multinational corporations (MNCs) based in Sub-Saharan Africa.

This is a moment of unprecedented expansion for companies in Sub-Saharan Africa. In pursuit of new markets and customers, more companies than ever before are reaching across borders to forge partnerships and open new operations. An impetus for this expansion has been a gradual reduction of the state's role in many Sub-Saharan economies - as regulator, investor and operator of key businesses. Relaxation of the public sector's influence has coincided with democratization, rising education and skill levels and the growth of an increasingly professional middle class.

Sub-Saharan Africa is a unique ecosystem for the development of MNCs; no other region in the world has such diversity of resources, economic structures, political systems, challenges to development and opportunities for 
growth. Not surprisingly, the most successful MNCs in this complex environment cut across a wide range of sectors and are based in countries across the region.

Sub-Saharan MNCs are defined as companies that are homegrown and solidly in the private sector, in the sense that their headquarters are in Sub-Saharan Africa and the state owns at most a minority stake. To analyze the characteristics of the most successful MNCs, this report identifies the 30 biggest from The Africa Report's 2010 rankings of the top 500 companies in Africa's key business sectors. The majority are mature companies that have expanded significantly during the recent wave of economic opening. Companies from Arab North Africa and South Africa were excluded because North Africa's distinct economic characteristics and South Africa's high levels of economic and financial development differentiate these regions from Sub-Saharan Africa

The top 30 MNCs' revenues outpaced growth in the world's major emerging regions and in the Organization for Economic Cooperation and Development (OECD). Their edge likely stems from chief executives' ability to plan for the long term and from the region's relative insulation from the financial crisis of 2008. Annual revenues ranged from \$240 million for Kenya Commercial Bank to \$2.4 billion for Oando, a Nigerian-based company. SubSaharan MNCs also performed well in comparison to other African companies. Between 2006 and 2009, their revenues grew faster - and more steadily - than the revenue of (The Africa Report, 2017)The Boston Consulting Group's (BCGs) African Challengers, a group of notable companies based primarily in North and South Africa.

Companies are headquartered in countries with significant differences in population and economic output. At the two ends of the spectrum are Nigeria, a \$200 billion economy home to more than 150 million people and almost half of the top $30 \mathrm{MNCs}$, and Mauritius, which has a population of fewer than 1.3 million people but boasts one of the highest gross domestic products in Sub-Saharan Africa of more than \$7,000 per capita (Source: 2010 Africa Development Indicators published by the World Bank Group).

The top 30 MNCs span five different industries, in addition to those with diversified businesses. Diversified companies' portfolios include a wide variety of businesses ranging from construction to agriculture to retail. Of the remaining top companies, the majority were in financial services, followed by petroleum, telecom, transport and tourism

\section{Expansion of Nigerian Transnational Companies}

\section{The Dangote Group}

The Dangote Group is currently the largest industrial conglomerate in West Africa and one of the largest in Africa. It has generated revenue in excess of $\$ 1.25$ billion since 2005 . The group is one of the leading diversified business conglomerates in Africa. It employs in excess of 11,000 people. Owned by the richest man in Africa, Aliko Dangote, the Dangote Group is a diversified conglomerates headquartered in Lagos, Nigeria, with interest across a range of sectors in Africa. Current interests include cement, sugar, flour, salt, pasta, beverages, and real estate, with new projects in development in the oil and natural gas, telecommunications, fertilizer and steel. The group focuses on provision of local, value-added products and services that meet the needs of the African population.(www.dangotegroup.org)

Dangote Cement is also the largest cement production company in Africa, with a market capitalization of $\$ 14$ billion on the Nigerian Stock Exchange, has subsidiaries in Benin, Cameroun, Ghana, Nigeria, South Africa and Zambia. In December, 2010, the group signed an agreement with the Government of Zambia to construct a $\$ 400$ million cement plant in Zambia. This was completed in 2015, and it has an annual output of 1.5 metric tonnes of cement.The table below shows the distribution of Dangote Cement across Sub-Saharan Africa and the annual output in metric tonnes.

Table 12: Distribution of Dangote Cement factories/plants across Sub-Sahara Africa

\begin{tabular}{llll}
\hline S/No & Country & Location of Factory/Plant & MTpa in millions \\
\hline 1 & Nigeria & Lagos, Port Harcourt, Kaduna & -- \\
2 & Cameroon & Daula, & 2.4 \\
3 & Kongo & Kongo Brazaville & 1.9 \\
4 & Ethiopia & Ethiopia & 1.5
\end{tabular}




\begin{tabular}{llll}
\hline 5 & Ghana & (Uses Nigeria;s Plants) & -- \\
6 & Senegal & Senegal & 2.1 \\
7 & Sierra Leone & - & 1.2 \\
8 & South Africa & South Africa & 1.5 \\
9 & Tanzania & Tanzania & 2.3 \\
10 & Zambia & Zambia & 2.6 \\
\hline
\end{tabular}

Source: compiled from 2016 Annual Regote Dahgote Group

\section{Construction of Terminals}

The terminals serve as discharge facility for the raw material requirements of all Dangote industries. This includes raw sugar, salt, wheat, gypsum, etc which are major raw materials for Dangote industries. As the group is expanding, there is corresponding need for the terminals to expand. In the case of Ghana, the investment in equipment and storage led to increase in productivity and reduction in vessel turnaround time. Most of the Ghanaian vessels berth on arrival, completely eliminating waiting time delay.

The table below shows the distribution of terminals of Dangote Industries and products across Sub-Saharan African countries.

Table 13: Terminals/warehouse of Dangote sugar, Dangote Salt, Dangote Tomato Paste, Dangote Flour and Dangote Macaroni across West Africa

\begin{tabular}{lll}
\hline S/NO & Location of terminals/warehouse & NTpa in millions \\
\hline 1 & Ghana & 1.5 \\
2 & Sierra Leone & 1 \\
3 & Cote d'ivoire & 1.8 \\
4 & Liberia & 1.4 \\
\hline
\end{tabular}

Source: Compiled from Dangote 2016 Annual Report

Table 14: Dangote's Trade with selected countries in Sub-Saharan Africa (USD millions)

\begin{tabular}{|c|c|c|c|c|c|c|c|}
\hline & 2005 & 2006 & 2007 & 2008 & 2009 & 2010 & 2011 \\
\hline \multicolumn{8}{|l|}{ Ghana } \\
\hline Cement & 564.9 & 596.6 & 385.7 & 498.5 & 611.2 & 657.6 & 855.2 \\
\hline $\begin{array}{l}\text { Sugar and } \\
\text { Salt }\end{array}$ & 18.5 & 13.9 & 88.8 & 75.5 & 57.1 & 116.4 & 116.4 \\
\hline Others & 546.4 & 371.4 & 409.7 & 535.8 & 539.5 & 541.2 & 738.8 \\
\hline \multicolumn{8}{|l|}{$\begin{array}{l}\text { Cote } \\
\text { d'Ivoire }\end{array}$} \\
\hline Cement & 264.1 & $253 . .6$ & 331.5 & 422.4 & 388.2 & 419.2 & 470.0 \\
\hline $\begin{array}{l}\text { Sugar and } \\
\text { Salt }\end{array}$ & 41.0 & 62.6 & 99.2 & 105.0 & 100.8 & 133.1 & 176.4 \\
\hline Others & 223.1 & 191.0 & 232.3 & 317.4 & 287.4 & 286.0 & 293.6 \\
\hline \multicolumn{8}{|l|}{ Zambia } \\
\hline Cement & 96.3 & 66.1. & 86.2 & 129.4 & 123.0 & 133.0 & 152.6 \\
\hline $\begin{array}{l}\text { Sugar and } \\
\text { Salt }\end{array}$ & 1.5 & 2.9 & 1.3 & 0.4 & 3.1 & 5.4 & 4.8 \\
\hline Others & 94.8 & 63.2 & 84.9 & 129.1 & 119.9 & 127.5 & 147.9 \\
\hline \multicolumn{8}{|l|}{ Tanzania } \\
\hline Cement & 34.0 & 35.4 & 29.4 & 30.3 & 59.3 & 68.9 & 66.5 \\
\hline
\end{tabular}




\begin{tabular}{llllllll}
\hline $\begin{array}{l}\text { Sugar and } \\
\text { Salt }\end{array}$ & 0.4 & 1.2 & 2.2 & 1.5 & 1.2 & 1.8 & 5.3 \\
Others & 33.6 & 34.2 & 27.2 & 28.8 & 58.1 & 67.1 & 61.2 \\
\hline
\end{tabular}

Source: compiled from the corresponding Annual reports (finance) of the Dangote Group

\section{Objectives and paths of Dangote's expansion}

Motivations for Dangote's Group expansion varied widely according to the country of operation, although they generally expanded from their major hub in Nigeria to other countries across Africa primarily for capital accumulation, some of the top executives interviewed for this paper identified the following objectives for their expansion:

- Diversify the resources within their business line

- Diversify lines of business to protect against cyclical and other vulnerabilitie Find a more favorable regulatory climate

- Achieve greater scale after saturating the local market

- Create networking effects between assets spread across the continent.

\section{Globacom Telecommunication}

Globacom Limited (GLO) is a Nigerian multinational telecommunications company headquartered in Lagos. GLO is a privately owned telecommunications carrier that started operations on 29 August 2003.GLO is privately owned by the Mike AdenugaGroup which also consists of ETB, now merged with the Sterling Bank, Conoil PLC, a petroleum marketing company, and Conoil Producing, a crude exploration company.(www.gloworld.org)

It began the expansion of its operation in other West African countries in 2008. In June 2008, Glo Mobile was launched in Benin. Glo Mobile showed unprecedented growth through the sale of 600,000 SIM cards in the first ten days of operation. Glo Mobile offered Per Second Billing, which charges subscribers for the exact airtime used. They also offered other value added services such as MMS (Multimedia Messaging Service), Glo Magic Plus news and information, vehicle tracking services, musical ring-back tones and mobile banking.

In May 2008, GLO acquired an operating license through its Glo Mobile division in Ghana and plans to capture $30 \%$ of the current 11 million subscriber market within 18 months of launchThey plan on achieving this goal by launching with bundled voice and Internet services for Ghana and through specifically targeting 'un-serviced' areas outside Ghana's two major cities, Accra and Kumasi. Glo Mobile was set to launch in Ghana the first quarter of 2010. This has however been postponed to the third quarter of 2011, and again to 2012. In January 2012, Glo Ghana opened the "Reserve your number" campaign, but still without opening the network. On 8 April 2011 GLO launched the sub-marine optical fiber GLO1, one part of its maiden operation in Ghana, to usher in another major player in the Ghana telecommunication industry. In October 2009, GLO acquired submarine cable landing rights and International Gateway Services in Côte d'Ivoire.

Table 15: Globacom Telecommunication operations across West Africa

\begin{tabular}{lll}
\hline S/NO & Countries/Operations & Total Assets in US \$m \\
\hline 1 & Republic of Benin & 118.5 \\
2 & Ghana & 138.6 \\
3 & Corte d'ivoire & 123,8 \\
\hline
\end{tabular}

Source: www.gloworld.org

GLO has an estimate of over 16 million subscribers across these three countries(April 2016) of which 12 million are internet subscribers. Globacom has the following range of products; Glo mobile, Glo Broad Access, Glo Gateway and Glo-1 coverage 


\section{Glo Mobile}

Glo Mobile, a subsidiary of GLO, is GLO's Mobile Network Unit. In the first year of operation, it had one million subscribers in over 87 towns in Ghana and over 120 billion Naira in revenues. ${ }^{[}$Glo Mobile has now spread to other cities in the Republic of Benin and Cote d'Ivorie

\section{Glo Gateway}

Glo Gateway, a subsidiary of GLO, is GLO's International Wholesale Voice and Data Exchange Trading Business Unit. Due to an expansion program which took place in 2008, Glo Gateway nowcovers 140 countries under its roaming services, and it is currently connected to 235 networks. 2008 also saw growth in Glo's data roaming for mobile phones, laptops and Black berry handsets, which has now spread to 72 networks in 29 countries. This now gives GLO the largest roaming coverage for voice and data in Africa-Glo Gateway recently acquired a license in Côte d'Ivoire.

In Cote d'Ivoire, Globacom is leveraging the existing network of cell phone airtime resellers and upgrading them into Glomobile

\section{Broadband access}

As a part of GLO's service offering, Glo Broad Access will be improved by the laying of the fibre optic cable for the metro ring, which is progressing steadily. The Glo Broad Access was launched on 24 November 2009. Glo Broad Access offers landline telephones, broadband internet and video, all on a single digital wire line. Glo- 1 has the potential to provide high-speed internet services, faster, more reliable and cheaper telecom services. Glo-1 will potentially facilitate foreign investment and employment opportunities especially to Africans.

In 2010, Glo Mobile introduced the Glo Fleet Manager in Ghana, which is a Vehicle Tracking solution. Glo Fleet Manager helps transporters/fleet operators in Ghana manage their fleet. They also introduced the Glo Mobile internet service in Ghana, and Cote d'Ivoire, which provides subscribers with access to internet sites which have been customized for mobile phone browsing.

In 2009, Glo Mobile launched Blackberry prepaid services in Ghana which gives subscribers options to pay daily, weekly or monthly for the service. Blackberry prepaid service gives subscribers free yahoo mail access and free blackberry messenger. The company also launched 3G High Speed Internet services in Ghana through the sale of its $3 \mathrm{G}$ modem.

On social development, GLO sponsors sports events in Ghana especially the Glo Ghana Premier League, the Ghana National Football Teams

\section{Contributions to Economic Development}

Business growth is vital for development and Nigerian transnationl companies presented above have great potentials to support the development of the communities where they do business across Sub-Saharan Africa. These potentials have been realized to a reasonable extent in additivingan effective economic development..Nigerian transnational companies have impacted their local communities in Sub-Saharan Africa in the following ways:

\section{New Products and Services}

Business expansion directly benefits consumers when investment addresses a shortage or introduces a new product or service that raises living standards. The expansion of Nigerian transnational companies has already resulted in several examples of their companies' foreign operations improving local living standards. For instance, when political turmoil in Zimbabwe put grain imports for Tanzania and Zambia at risk, Dangote Industries Limited brought improved seed stocks to both countries and contributed to the development of the agricultural sector. Another example is Globacom construction of fiber optic cables, which resulted in a significant increase in broadband capacity in the Republic of Benin. Since the construction of the cable began in 20014, internet usage in the country has risen by 1,200 to 1,500 percent in most cities where Globacom serves. 


\section{Local Sourcing}

Companies can help host countries to develop by creating product lines that use local resources; doing so can increase credibility of their brand and establish their reputation. The Dangote Group, for instance, launched a homegrown-tomato paste in order to use local crops for tomatoe paste production in Uganda. This line of business has spread across Sub-Saharan Africa since it began in 2014

\section{Additional Complementary Investment}

The expansion of companies whose business provides the foundation for economic growth also results in complementary investments by companies in related industries. UBA estimates that its entry into a country is associated with $\$ 5$ billion to $\$ 6$ billion in related investments in infrastructure. GTB has done the same for the financial infrastructure in Rwanda, Kenya,Uganda and Gambia by helping their governments set up stock exchanges.

\section{Workforce Development}

Some Nigeria's operating across Sub-Saharan Africa also have programs to encourage local development. One of the best known is Dangote Group, which sponsored training programs for local workers near its cement factories inEthiopia, Cameroon and Tanzania. The trained workers participated in the construction of the factory facilities, solving a labor problem, and the knowledge they gained helped the local firms they worked for attain a higher overall skill level and serve other major clients as well.

\section{Conclusion}

The profit motive is of course important for understanding firm behavior, but it is not the only norm that shapes firm's actions. The experience of Nigerian indigenous cross-border companies in Sub-Saharan Africa suggests that in addition to "instrumental pursuit of profit maximization," business actors also have "principled beliefs" about regional identity which, when acted upon as a group or by leading actors, is capable of creating and disseminating norms that can act as barriers to intra-African trade. Additionally, contrary to the negative perceptions of African economies in the academic literature and popular imagination, Africa's home-grown firms had been central to the region's remarkable recovery from the 2008 global economic crisis.

By removing the key constraints to increasing the size and efficiency of the private sector, regional integration facilitates the formation of larger markets through trade liberalization and harmonization, and increases the potential scale of business and profit opportunities. And macroeconomic policy harmonization across most regional economic communities reduces economic uncertainty and risk, stimulating private sector activity.

Finally, focusing on private sector contribution to economic development of African countries does not imply the disappearance or impotence of the African state system. In fact, the critical role played by continental and regional political/economic organizations such as OAU/Au, ECOWAS, COMESA and others, and trade regulatory agencies highlighted in this study clearly demonstrate the continuing significance of the states and its agencies, no matter their weakness or stage of "failure." On the other hand, private trade and investments alone are not the panacea to problems economic development in Africa, but critical stakeholders in economic revival of the continent. Their role in effectiveness of business as part of multiple-actor coalitions and policy networks that are developing new discourse, ideas, and norms especially within Sub-Saharan Africa will never be overemphasized.

As a class, these Nigerian transnational companies present attractive opportunities for investment because of their proven returns and potential to grow across the continent and beyond. Their expansion through merger acquisitions demonstrates the potentials of Strong African firms in promoting industrial restructuring and creation of large market. Indigenous Nigerian companies have taken advantage of positive economic, political and social trends to grow into a diverse group of successful multinationals.. Though these companies have received little international attention, their performance has outpaced business growth in major emerging and developed markets. This growth is projected to continue in the next decade as these companies continue to expand across Africa and beyond. Successful Nigerian transnational companies have adapted modes of expansion used globally to fit the unique characteristics of the countries in which they operate. Keys to success shared these companies include taking time for due diligence, looking for the right policy environment, being conscious of cultural differences and seeking long term anchor clients and partners. These approaches have allowed Nigerian transnational companies to enter and thrive in difficult business environments. Their expansion has contributed to sustainable economic development in the countries where they operate. Core business activities often open markets and provide 
consumers with more choices. Additionally, companies have taken an active role in the communities where they do business by raising skill levels, supporting education and deepening the capacity of local suppliers.

Transnaonal companies can be a powerful engine for development in Sub- Saharan Africa. By engaging with local communities in the countries where they do business, they can share knowledge, deepen workers' skills and professionalize suppliers. In the long term, these collaborations can promote employment and raise living standards in a sustainable way. However, the growth of transnational companies will depend in part on the actions of governments in their host countries. Currently, they are succeeding in policy environments that would be considered deal-killers in many other regions of the world; they are also overcoming limitations of public services, bureaucracy and infrastructure that stem from limited state capacity. Governments can foster a better investment climate by improving policies and regulations based on input from transnational companies operating in their countries.

This study enriches international economic development scholarship on African regional economic integration and comparative economic development by adopting the south-south developmental approach in Sun-Saharan African context. Instead of relying solely on foreign direct investments and aid from the advanced economies, the southsouth approach advocated the cooperation of the developing countries - the so called third world, in advancing their economies. This study is a paradigm shift towards emphasizing the potentials of intra-Africa private sector trade and investment in addressing the rising competition in global market and the regional integration. It has become obvious that for Africa to get out of its low-level economic trap and lay the foundation for any significant process of economic development. New economic strategies would have to be formulated and pursued vigorously to install a new economic order based on the firm principle of self-reliance and sustainment at the regional level.

\section{References}

Adelegan, J. O. 2000, Foreign Direct Investment and Economic Growth in Nigeria: A seemingly unrelated model". African Review of Money, Finance and Banking, Supplementary issue of "Savings and Development" 2000.pp.525. Milan, Italy.

African Business (2013) African Agricbusiness-Turning Green to Gold, No. 400 August/September, London: IC publication

Alejandro D. (2010): Bautista conference foreign direct investment Mexico, United States, Canada NAFTA, Presentation Transcript.

Alfaro C, A. Chanda, S.Kalemi-Ozean and S.Sayek (2003)'FDI and economic growth: The role of local andfinancial markets" Journal of International Economics

Ariyo, A. (1998).“Investment and Nigeria's Economic Growth”.In Investment in Growth Process Proceedings of Nigerian Economic Society Annual Conference 1998, pp.389-415. Ibadan,Nigeria.

Bemde-Nabende, A., J. Ford, S. Sen and Slater J (2002). "Foreign Direct Investment in East Asia: Trends and Determinants". Asia Pacific Journal of Economics and Business 6(1): 4-25.

Chenery, H. B. and Stout, A. (1966): "Foreign Assistance and Economic Development". American Economic Review.55, pp.679-733.

Durham, J.B. (2004): “Absorptive capacity and the effects of foreign direct investment and equity foreign portfolio investment on economic growth;"European Economic Review, 48 (2): 285 - 306.

Ewe-Ghee Lim (2001) "Correlation with Economic Growth; Determinant of, and the Relation between Foreign Direct Investment and Economic Growth” IMF Working paper.No: 01/175

Ewe-Ghee Lim (2001) "Correlation with Economic Growth; Determinant of, and the Relation between Foreign Direct Investment and Economic Growth” IMF Working paper.No: 01/175

IMF (2009).Fiscal Policy in Sub-Saharan Africa in Response to the Impact of the Global 
Jecheche, P. (2011). "Investment and Growth Relationship: An Empirical Assessment in Zimbabwe."Journal of International Business and Cultural Studies. 13(3): 1 - 11.

Lall (2002): Foreign investment transactional and development countries, Macmillan Press Ltd, London.

Ndikumana, L. (2005). “Can Macroeconomic Policy Stimulate Investment in South Africa? New Insights from Aggregate and Manufacturing Sector-level Evidence.’University of Massachusetts Economics Department Working Paper Series.Paper 50.http://scholarworks.umass.edu/econ_workingpaper/50.

Nwankwo, O.G, Ademola, O. and Kehinde, O (2013).“Effects Of Globalization On Foreign Direct Investment In Nigeria."Lorem Journal of Business and Economics (LJBE) Volume 1 No 1 pp 11-17.

Obwana, Morios B.(2001), "Determinants of FDI and their impact on economic growth in Uganda" . African Development Review 2001, Blackwell Publishers Oxford.Uk.46-80.

Ogiogio, G. O. (1995). "Planning horizon, government expenditure and economic growth in Nigeria”.In A. Ariyo, ed., Economic Reform Macroeconomic Management in Nigeria. Ibadan: The Centre for Public Private Cooperation.

Oshikoya, T. (1994)."Macroeconomic Determinants of Domestic Private Investment in Africa: An Empirical Analysis."Economic Development and Cultural Change 42(3): 573-596.

Oyinlola, O. (1995).“External Capital and Economic Development in Nigeria (1970-1991)”. The Nigerian Journal of Economic and Social Studies, 37 (2\&3): 205-22.

Ricardo, H , Hwang, J and Rodrik, D (2005). What you export matters. "Working papers" Center For International Development at Harvard University.

The Africa Report, (2017).“Top 500 Companies in Africa.” Retrieved from http:/www.theafricareport.com/ rankings/top-500-companies.html

United Nations Economic Commission for Africa, Investment Policies and Bilateral Investment Treaties in Africa: Implications for Regional Integration 